\title{
FUTURE OF HOUSEHOLD RESOURCES AND EXPENDITURE AS THE INDICATORS OF SUSTAINABLE DEVELOPMENT IN UKRAINE
}

\author{
Olena Berezina \\ Cherkasy State Technological University, Ukraine \\ Iryna Honcharenko \\ Cherkasy State Technological University, Ukraine \\ Lesia Berezhna \\ Cherkasy State Technological University, Ukraine
}

\begin{abstract}
The main concept advantages of investigating the interrelation between household income and expenditure in the context of achieving sustainable development goals are the possibility of coordinating the general development of benchmarks with the specific existing conditions and perspectives of countries and regions. In this context, an urgent challenge is not only the establishment of targets but also the development of a system of indicators to determine the degree of progress in each direction. The purpose of this study is to develop a system of indicators for monitoring the state of Ukrainian households aimed at determining the sustainability level of regional development. The main goals of sustainable development, the success of which can be studied based on the state monitoring of households, are identified in the paper. The modern global trends of the state, size, and finances of households are analyzed. Sustainable development objectives and indicators for monitoring the state households, which are likely to be used to establish the success of these tasks at the regional level, are identified.
\end{abstract}

Keywords: sustainable development, household, region, sustainable development goals (SDG), household incomes, household expenses, differentiation of living standards.

DOI: http://dx.doi.org/10.15549/jeecar.v7i3.431

\section{INTRODUCTION}

The concept of sustainable regional development derives from the global concept of sustainable development, the key provisions and conceptual regulations of which are elaborated in detail in the declarations and reports of various international organizations, in particular the UN and the Club of Rome. Thus, in 
June 1992, the need to recognize the principles of sustainable development as the key guidelines for the formation of a new just society was declared. One of the advantages of this concept is the ability to align common development guidelines with the specific existing and prospective conditions of countries and regions (social, geopolitical, environmental, economic, historical, etc.). In this context, the challenge is not only to set targets but also to develop systems of indicators that will determine the degree of progress in each of the areas.

\section{REVIEW OF THE LITERATURE}

The valid formation and distribution of household income has traditionally been the basis for the stable development of any country in the course of mankind's evolution. The founders of classical economics - A. Smith and D. Ricardo - believed income distribution to be the basis for theoretical research in political economy and significant disparities in it to be the main obstacles to economic development. In the early twentieth century due to the rapid development of economies, this problem needed a theoretical background and relevant practical solutions. In the Twentieth Century, Western economists such as H. Dalton (1920), A. Atkinson (1970), and A. Dayton (1997) et all suggested substantive theoretical constructs.

Research explored the experience of many countries regarding the dynamics of incomes, the conclusion can be drawn that a slight disparity contributes to the development by stimulating employees to provide real results for the corresponding wages and vice versa, a significant separation between social groups forms a depressive mood, causes social tension. The similar situation occurring in Ukraine.

Currently, there is a significant amount of research dealing with the difference of incomes, ranging from small analytical and statistical reviews to longer monographs. Complex research has been done by foreign scholars such as V. Tanzi (1999), F. Schneider (2005), and Chandra S. \& Yadoo J. (2018), Bosch, G., Kalina, T. (2016) et al. Ukrainian scholars S. V. Shubina, O. Y. Miroshny (2010); L. Petkova, I. Zagorulko, D. Palamarchuk (201investigated this problem. These studies by foreign and domestic scientists, however, do not discuss all the existing problems that have arisen in Ukraine in the current circumstances. Therefore, there is a need for further scientific substantiation of theoretical and practical bases of household income differences.

According to UN recommendations, a household is a group of persons who have reached certain agreements among themselves to ensure their consumption. McConnell K. \& Bru S. (2003) believe that "...the household is the supplier of all economic resources and at the same time the consumer of the greater part of the national product" (p. 77). G. S. Becker (1957) emphasizes the importance of the productive function that households perform in modern conditions. The system of national accounts (Statistical collection "Costs and resources of households of Ukraine in 2017") defines a household as a small group of people living in one room and who fully or partially combine their income and property and jointly consume certain types of goods and services. Cohabitation and household management provide for common expenses, that is, household members must have a common budget to meet their needs" (p.4). According to the All-Ukrainian Population Census: Law of Ukraine dated 19.10.2000 No. 2058-III, a household is a collection of persons who live together in one or a part of a dwelling, provide for themselves with everything necessary for living, maintain a common household, and fully or partially combine and spend funds.

\section{METHODOLOGY OF THE RESEARCH}

According to the results of the UN Summit, held in the framework of the 70th session of the UN General Assembly in 2015, the Development Agenda 2030 and Seventeen Sustainable Development Goals (SDG) were adopted, which are the main priorities of social development for the near future. The monitoring and analysis of the 17 SDG and 169 targets of the new agenda will be carried out through a set of global indicators. It should be noted that the UN reports on the achievement of the sustainable development goals (published for the period 2014-2016) show that the development of a unified system of indicators continues. It should be noted that, having identified 17 goals and 
169 targets as their highest priorities, countries are developing their own national indicators that will help to monitor the progress of the goals and targets.

Ukraine is one of the countries that has committed itself to the transition of the economic system to the principles of sustainable development. In particular, in the document "The Strategy of Sustainable Development of Ukraine - 2020" (about "The Strategy of Sustainable Development Ukraine2020": Decree of the President of Ukraine No. $5 / 2015$ dated January 12,2015 ) the concept of sustainable development is defined as the basic imperative of affirming the ideas of dignity and freedom. Sustainable Development Goals (SDGs) in Ukraine is the new system of mutually agreed management measures for the economic, social and environmental measures aimed at building public relations based on trust, solidarity, equality of generations, and a secure environment. In September 2017, the Government of Ukraine presented the National Report "Sustainable Development Goals: Ukraine", which defined the basic indicators for achieving the SDGs. The report presents the results of the adaptation of the 17 global SDGs to the specifics of national development. Taking into account the principle of "leave no one behind" and using a wide range of information, statistical and analytical materials, a national system of SDGs was developed (86 development objectives and 172 indicators to monitor their implementation).

S. Yuri and T. Kizima (2008) mentioned that the global indicators are designed to analyze trends towards achieving globally the defined SDGs by 2030 and to make international comparisons. However, such indicators are not always acceptable in the national context. The indicators for monitoring at the national, regional and local levels should be developed taking into account the capabilities of the national statistical system.

The success of the implementation of the fourteen tasks for the achievement of the SDGSs in the regions of Ukraine (from the above 86) can be verified using 28 quantitative indicators of the condition of the households. The information about the condition, volumes, average values and distribution of household finances provides an opportunity to conclude about the level and sustainability of territorial development. These indicators relate to 6 goals (Goal 1. Overcoming poverty; Goal 2. Overcoming hunger and developing agriculture; Goal 3. Good health and well-being; Goal 4. Quality education; Goal 6. Clean water and adequate sanitation; Goal 10. Reduction of inequality).

To determine the success of achieving the sustainable development goals of household income and expenditure, this paper uses classical econometric methods and models, which are a universal tool for this kind of analysis. The forecast values of the studied indicators are proposed to be obtained using the exponential smoothing method. The latter has been chosen because it belongs to adaptive forecasting models; that is, to data discounting models that can quickly adapt their structure and parameters to changes in external conditions characteristic of household income and expenditure. Along with this, to summarize the results of the study and determine the importance of indicators, the paper uses multidimensional ranking and the method of expert assessments.

\section{EMPIRICAL ANALYSIS}

The number of households in Ukraine during 2010-2018 decreased by $13.83 \%$ - from 17 to 14.935 million units, due to the challenging demographic situation in the country. The average household size in Ukraine during the study period ranged from 2.59 to 2.58 persons, corresponding to the European average (from 2.0 to 2.8 people).

Average household sizes vary significantly in different continents as well as across countries. According to the UN (The world needs to build 2 billion new homes over the next 80 years), recent trends over the past 50 years have also shown a decline in household sizes. In France, for example, the average household size fell from 3.1 in 1968 to 2.3 in 2011, while the country's birth rate fell from 2.6 to 2.0 births per woman. In Kenya, the average household size decreased from 5.3 persons per household in 1969 to 4.0 in 2014, respectively, reducing the birth rate from 8.1 to 4.4 births per woman. 
The state of volumes, average values and distribution of household finances allow us to conclude the level of development of the territory and the continuity of this development. As a result, the success of the achievement of the sustainable development goals - poverty reduction - can be assessed using the following indicators: the proportion of the population whose average equivalent total expenditures per person are below the actual (estimated) cost of living; the proportion of people whose daily consumption is below 5.05 US dollars; the proportion of poor who are maintained by the state social support in the total poor population; the ratio of the levels of poverty of households with children to households without children; expenditures on food out of total household expenditure, etc. According to recent studies, the world as a whole is getting richer, but the main problem is the increasing uneven distribution of this wealth. According to the Credit Suisse Global Report (Chart of the day: Which countries have the largest share of global household), during 12 months to mid-2018, total global household wealth increased by nearly 14 trillion USD to 317 trillion USD - a growth rate of $4.6 \%$. Meanwhile, average wealth rose by only 3.2 percent to a record of 63.1 thousand USD per person. The greatest achievements in this direction are demonstrated by North America and Europe, which together hold $60 \%$ of the total wealth of households, while only $17 \%$ of the world's households are located in their territory.

According to a report by Oxfam (Reward work, not wealth: to end the inequality crisis, we have to build an economy for ordinary people, not the rich and powerful), the poorest half of the world has not seen an increase in wealth since 2010. Conversely, the wealth of billionaires grew by an average of $13 \%$ - six times faster than the wages of ordinary workers, which increased by an average annual amount of only $2 \%$.

As for Ukraine, the results of the analysis of the dynamics of the average monthly total resources and household expenditures for 20102018, are shown in Figure 1.

Overall, during the period under review, average monthly total resources per household exceeded similar average monthly total expenditures by an average of 13.65 percent or 47.24 USD. The largest percentage difference occurred in 2012 and 2013 - 15.38\% (69.13 USD) and $17 \%$ (81.35 USD), respectively, and in absolute terms 58.66 USD in 2018 , or $19.2 \%$.

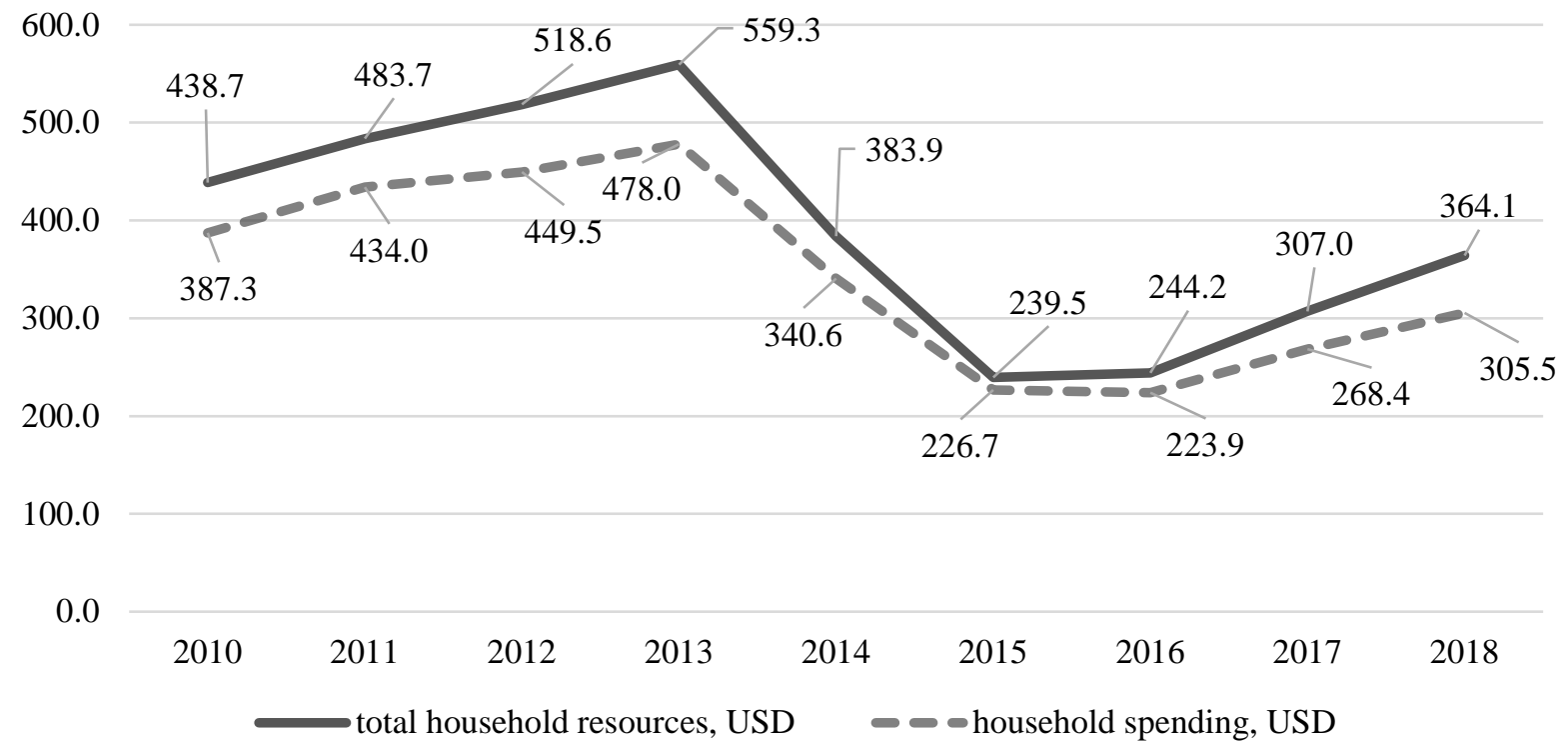

Figure 1. Dynamics of the average monthly total resources and expenditures of households in Ukraine, per household (USD).

Note: The data is from calculations by authors based on the Statistical collection "Expenses and resources of households of Ukraine in 2018" 
The average growth rate of total household resources for the period under review is $2.3 \%$, with the largest growth occurring in 2017, or $25.33 \%$, and the largest drop, in 2015 , by $37.62 \%$. The average growth rate of household spending is $2.92 \%$, while the trend of intensive and slowest growth is similar to the indicators of resources up 19.9\% in 2017 and 33.45\% in 2015. If in general, to describe the growth rates of resources and expenses of households, they are jumpy. Income had higher growth rates than expenses in 2012-2013 and 2016-2018, but falling growth rates in 2014-2015, and in other periods growth rates of expenses prevailed. Adjusting the growth rate of household resources and expenditures for the inflation index within each year significantly changes the picture: in 2014 and 2015, real total household resources decreased by $22.45 \%$ and $28.65 \%$, respectively, and expenditures decreased only by $18.74 \%$ and $21 \%$, respectively. Since 2016 there has been an increase in indicators - by 6.85\% (2016) and 17.18\% (2017) - of total household resources, adjusted for the inflation index and 3.12\% (2016) and 11.11\% (2017) of total costs, adjusted for the inflation index. The tendency of the growth of indicators with the simultaneous excess of rates of growth of resources (in 2.2 times in 2016 and 1.55 times in 2017) over expenses proves to have essential progress in the dynamics of indicators.

The correlation and regression analysis made it possible to determine the relationship between average monthly total resources $(X)$ and household expenditures $(y)$ for the studied period. As a result, a linear model is constructed

$$
y=20,56+0,83 x
$$

which indicates that, with resources growing by 1 USD, average monthly household expenditure increases by 0.83 USD.

In the course of the analysis, with the help of the correlation coefficient, it is proved that there is a rather close relationship between resources and costs, as evidenced by the value $r_{x y}=0.995$. The coefficient of determination showed that 99.2\% of the total fluctuations in household expenditures are due to the influence of resources on them, and the other $0.8 \%$ of fluctuations are due to the influence of other factors not studied in the model.

The economic interpretation of the model is carried out, the result of which is the determination that an increase in the average monthly resources of households by $1 \%$ will raise the costs by $0.94 \%$.

Using the exponential smoothing method for the period under review, household incomes (monthly average) were projected for 2019. They could be 259.09 USD, which is 28.84 USD less than in 2018. Using model (1), the projected value of household expenditure could be as high as 234.98 USD, or $10.26 \%$ less than resources.

However, this pessimistic forecast takes into account only the previous trends in resources and does not take into account the potential change in the economic situation in Ukraine, which may be caused by reforms as a result of its presidential and parliamentary elections.

It should be noted, however, that this level is influenced by many factors including political, migratory, demographics, mental, financial, etc, which lag far behind a real income. Taking into account the significant level of the shadow economy (according to different experts estimates from 35 to 55\% of GDP), a low level of social standards (minimum wage, 137.86 USD, with the minimum living wage for able-bodied persons being 68.3 USD, which at 52.01 USD, or $76.35 \%$, is less than the actual subsistence minimum, and a minimum pension of 55.04 USD as of December 1, 2018), fairly significant unemployment rates in the range of $10 \%$ of the working population, and the depreciation of UAH during 2014-2016 by more than three times, it becomes apparent that the standard of living of the majority of the population in Ukraine is lower compared to physiological standards in other European countries.

To clarify the situation regarding income differences of the population, the appropriate analysis is done based on the data in Table 1.

Evaluating these figures, the following conclusions can be drawn: the population with average total income per month below the current minimum wage amounted to 20.2 million persons in 2015 , or $51.9 \%$ of the total population; in 2016, these levels are 10.6 
million individuals and $26.6 \%$ of the total population in 2018, respectively.

Quintile difference coefficients of the population total income and assets ratio (for total income) in 2018 constituted 2.0 and 3.3 times, respectively, which is almost associated with most of Europe, although it should be taken into account that the survey does not fully consider the current real facts of life, namely certain problems in obtaining information about the actual state of revenues stimulated in the mentality of the nation, a significant transfer of funds to Ukraine by "migrant workers", the introduction of e-declarations of income in 2016, etc.

Table 1. The difference in living standards

\begin{tabular}{|c|c|c|c|c|c|c|c|c|c|}
\hline & 2010 & 2011 & 2012 & 2013 & $2014^{2}$ & $2015^{2}$ & $2016^{2}$ & $2017^{2}$ & 2018 \\
\hline \multicolumn{10}{|c|}{$\begin{array}{l}\text { The number of people with the average equivalent to the total income per month is below the } \\
\text { statutory subsistence minimum: }\end{array}$} \\
\hline million people & 3.6 & 3.2 & 3.8 & 3.5 & 3.2 & 2.5 & 1.5 & 0.9 & 0.5 \\
\hline $\begin{array}{l}\text { percentage of the total } \\
\text { population }\end{array}$ & 8.6 & 7.8 & 9.0 & 8.3 & 8.6 & 6.4 & 3.8 & 2.4 & 1.3 \\
\hline \multicolumn{10}{|c|}{$\begin{array}{l}\text { The number of people with the average equivalent to the total income per month is below the } \\
\text { statutory subsistence minimum: }\end{array}$} \\
\hline million people & $\ldots$ & $\ldots$ & $\ldots$ & $\ldots$ & 6.3 & 20.2 & 19,8 & 13.5 & 10.6 \\
\hline $\begin{array}{l}\text { percentage of the total } \\
\text { population }\end{array}$ & $\ldots$ & $\cdots$ & $\cdots$ & $\cdots$ & 16.7 & 51.9 & 51.1 & 34.9 & 27.6 \\
\hline \multicolumn{10}{|l|}{ Reference: } \\
\hline $\begin{array}{l}\text { the average size of the } \\
\text { legally defined minimum } \\
\text { wage (average per person } \\
\text { per month, USD) }\end{array}$ & 106.3 & 114.7 & 130.5 & 139.3 & 98.9 & 56.2 & 54.3 & 60.3 & 64.2 \\
\hline $\begin{array}{l}\text { the average annual amount } \\
\text { of actual minimum wage } \\
\text { (average per person per } \\
\text { month, USD) }\end{array}$ & $\cdots$ & $\cdots$ & $\cdots$ & $\cdots$ & 114.2 & 103.3 & 103.4 & 110.6 & 120.0 \\
\hline $\begin{array}{l}\text { Differentiation factor } \\
\text { quintile of the total income } \\
\text { of the population, }\end{array}$ & 1.9 & 1.9 & 1.9 & 1.9 & 1.9 & 1.9 & 1.9 & 1.9 & 2.0 \\
\hline $\begin{array}{l}\text { Quintile assets ratio (total } \\
\text { income) times }\end{array}$ & 3.5 & 3.4 & 3.2 & 3.3 & 3.1 & 3.2 & 3.0 & 3.3 & 3.3 \\
\hline
\end{tabular}

Note: Data is from calculations by authors based on SSU Statistical collection "Differentiation of living standard"

${ }^{1}$ The part of the zone of the antiterrorist operation is excepted.

According to the study of subjective poverty and social self-identification ("Self-assessment of income level by households in Ukraine for 2017" by State Statistics Service of Ukraine),
Ukrainian households were asked to determine which class they belong to in assessing material well-being. According to the survey, about $71 \%$ of respondents identified themselves as poor 
(74\% in 2016), around $29 \%$ as nonpoor but not yet middle class (26\%), $0.6 \%$ as middle class $(0.5 \%)$ and almost none of the respondents considered themselves wealthy. This response pattern applies to all groups of households, regardless of where they live, or whether they have children or not. Households were asked to specify how much money is needed on average for each person per month not to feel poor. Most households reported an income of 338.5 USD 376.0 USD and more than 376.0 USD (by 22\%) (in $2016-16 \%$ and $12 \%$, respectively). The next most common estimate was an income of 150.5 USD - 188.0 USD, which was indicated by $16 \%$ of respondents (23\%).

As can be seen readily, one of the main goals of sustainable development, namely overcoming poverty, is very relevant for Ukraine. And this is even though, according to calculations carried out by the Institute of Demography and Social Research named after M. V. Ptukha of the National Academy of Sciences of Ukraine, the level of relative poverty in 2018 compared to 2017 decreased by 0.3 percentage points and amounted to $24 \%$. The limit of poverty has reached a level of 96.36 USD average per person per month and has increased by $16 \%$.

Analyzing the structure of total spending by households in Ukraine (Fig. 2), it can be seen that $70 \%$ of expenses is for the purchase of food, soft drinks, utilities, clothing, shoes, household items and communications, $15 \%$ is other consumer and non-consumer spending and only $15 \%$ is on recreation, health care, education, car purchases, restaurants, hotels and savings, that is, the needs of the "highest level".

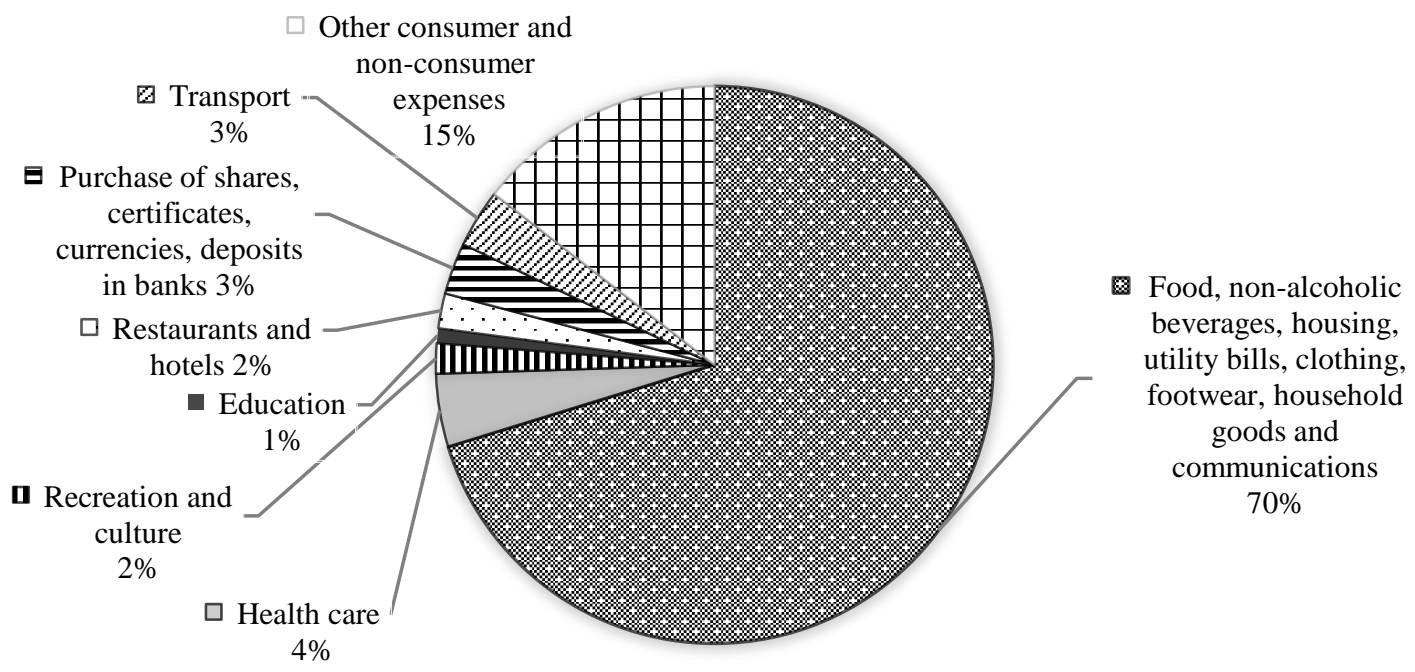

Figure 2. The structure of monetary expenditures of Ukrainian households in 2018

Note: Data is from calculations by authors based on SSU Statistical collection "The structure of households overall costs"

The dynamics of total household expenditures in Ukraine and expenditures of the "highest level" is shown in Fig. 3. 


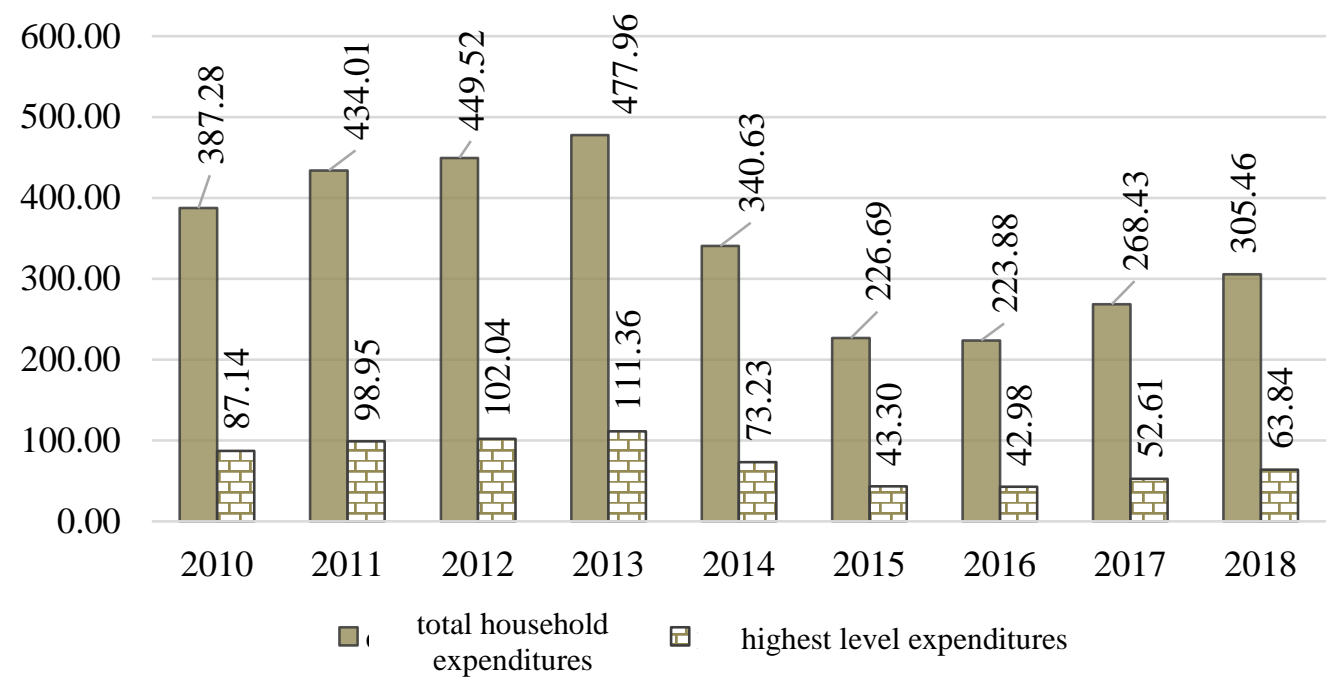

Figure 3. Dynamics of total household expenditures and "highest level" expenditures in Ukraine Note: Data is from calculations by authors based on SSU Statistical collection "The structure of households overall costs"

Analysis of the data allows us to build a model of the relationship of these costs:

$$
y=-18,39+0,27 x
$$

by which it is seen that with the increase in total expenditure $(x)$ by 1 USD, the cost of the highest level $(y)$ increases by 0.27 USD. The relationship is strong enough to indicate that $99.8 \%$ of the change in top-level household spending depends on the change in total spending, and $0.2 \%$ is the effect of other factors that are not investigated in the model. Model (2) is adequate and statistically significant.

Let us assess the current situation with secondary household spending in the regions of Ukraine. It should be noted that generalizing all these indicators will help to build the construction of an integral indicator of expenditure of the "highest level" (/HLE), the method of calculation of which is described below by L. V. Berezhna and O. I. Snytyuk (2016):

1. Formation of a set of indicators and determination of their characteristic values. We propose to characterize the "highest level" cost indicators according to such basic criteria as the cost of:

- health care ( $\left.\mathrm{x}_{1 \mathrm{i}}, \mathrm{USD}\right)$,
- recreation and culture ( $\left.\mathrm{x}_{2 \mathrm{i}}, \mathrm{USD}\right)$,

- education ( $\mathrm{x}_{3 \mathrm{i}}$, USD),

- restaurants and hotels ( $\mathrm{x}_{4 \mathrm{i}}, \mathrm{USD}$ ),

- purchase of shares, certificates, currency, Bank deposits ( $\mathrm{x}_{5 \mathrm{i}}$, USD),

where $i$ is the region for which the calculation is made $(i=\overline{1, n})$.

2. Normalization and standardization of indicators. As it is known, the task of normalization is the transition to this scale of measurement, when the "best" indicator corresponds to the value of 1 and a "bad" value is 0 . All proposed indicators are stimulants. We therefore standardize the indicators, comparing them with the average result in Ukraine $\left(a_{j}\right)$, according to the formula:

$$
z_{i j}=\frac{x_{i j}}{a_{j}},
$$

where $i$ is the region for which the calculation is made $(j=\overline{1, m})$.

3. Calculation of the integral index. An integral indicator of "highest level" expenses (/HLE) according to the following formula is proposed:

$$
I_{H L E_{i j}}=\sum_{k=1}^{5} d_{k} z_{k_{i j}},
$$

that is 
$I_{H L E_{i j}}=0,3 z_{1_{i j}}+0,2 z_{z_{i j}}+0,2 z_{3_{i j}}+0,175 z_{4_{i j}}+0,125 z_{5_{i j}}$

where $z_{1_{i j g}}, z_{2_{i j g}}, z_{3_{i j g}}, z_{4_{i j g}}-$ normalized and standardized values, respectively, of expenses for health protection $\left(\mathrm{x}_{1}\right)$, on recreation and culture $\left(x_{2}\right)$, education $\left(x_{3}\right)$, restaurants and hotels $\left(x_{4}\right)$, the purchase of shares, certificates, currency, deposits in banks $\left(x_{5}\right) ; I$ is the region for which a calculation of $(i=\overline{1, n})$ is performed, $j$ is the index, which is calculated $(j=\overline{1, m})$.

It should be noted that the coefficients

$d_{k}\left(k=\overline{1,5} ; d_{1}=0,3 ; d_{2,3}=0,2, d_{4}=\right.$ 0,$\left.175 ; d_{5}=0,125 ; \sum_{1}^{5} d_{k}=1\right)$ are obtained by the method of expert assessments and indicate the importance of each of the indicators in the integral $x_{1_{i j}}, x_{2_{i j}}, x_{3_{i j}}, x_{4_{i j}}, x_{5_{i j}}$ indicator $I_{H L E_{i j}}$. The formula shows that health care costs are the highest. The "highest level" integral cost estimate is calculated by the formula $I_{H L E_{i}}=\frac{1}{5} \sum_{1}^{5} I_{H L E_{i j}}$.

The data $I_{H L E_{i}}$ of the State Statistics Committee of Ukraine for 2018 on cash expenditures of households by regions have been used for the construction. The obtained results of the integral indicator are summarized in Fig. 4.

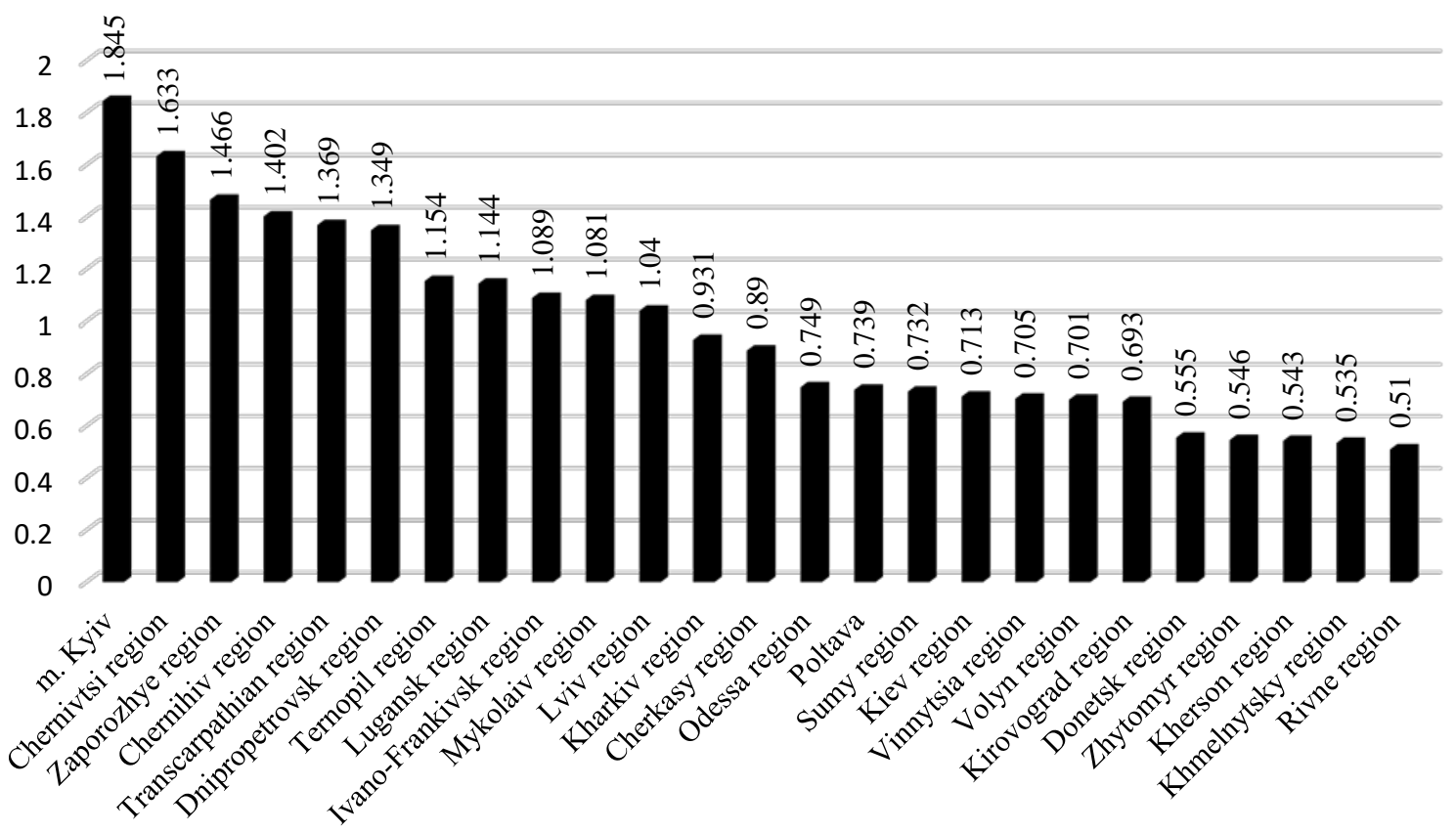

Figure 4. Ranking of regions of Ukraine on the integral indicator of "highest level" expenses in 2018

Note: Data is from calculations by authors based on SSU Statistical collection "Households money expenses by region of Ukraine in 2018."

\section{CONCLUSIONS}

Household income is an important socioeconomic indicator of the social development of any country and its differentiation leads to stratification on a property principle. This study has identified the level difference of this, which, in general, does not reflect domestic facts of life in comparison with official statistical data.

Monitoring of the condition of the households allows for the determination of the power of regional development and the success of achieving the sustainable development goals in the territory.

The developed model of connection of total household expenses and expenses of "highest level" in Ukraine proves that with the growth of total expenses $(x)$ by 1 USD the cost of the highest level $(y)$ increases by 0.27 USD. The relationship is strong enough to indicate that $99.8 \%$ of the change in top-level household 
spending depends on the change in total spending, and $0.2 \%$ is the effect of other factors that are not investigated in the model. The model is adequate and statistically significant.

Thus, it can be concluded that a household is more satisfied with life and does not feel poor if it can spend more money on non-urgent needs: namely on health care; transport; recreation and culture; education; restaurants and hotels; purchase of shares, certificates, currency, deposits in banks.

The results of the study indicate that 11 regions of Ukraine have generalized indicators of secondary costs above the national average, and 14 regions are below it. The cost of healthcare, recreation, education, transportation, deposits in banks are mainly affordable by the households of Kyiv, Chernivtsi and Zaporizhia regions with values $I_{\mathrm{BBP}_{i}} 1.845$; 1.633 and 1.466 , respectively. The residents of Donetsk, Zhytomyr, Kherson, Khmelnytsky and Rivne regions can buy less and have an integral index of less than 0.6. Thus, households in most regions of Ukraine are not satisfied with the opportunities available to ensure an adequate standard of living.

The theoretical significance of the study is that taking into account the results of monitoring household incomes and their impact on the sustainability of social development will formulate appropriate proposals to reduce the differentiation of household incomes and ensure sustainable development.

The practical significance of the study is due to the developed correlation models of household expenditures (by the type of expenditure and by the regional distribution), developing practical recommendations for cost management and optimization of the ratio of income and expenses, both by type and in the regional distribution.

The results of monitoring can be used for identifying the impact of regional progress on poverty alleviation and reducing inequalities, improving the health and well-being of the population, ensuring quality education, access to clean water and appropriate sanitation conditions.

The outcomes of the research include economic and social effects. The economic one lies in the fact that the investigated peculiarities form conditions that reduce the level of income differentiation of the population by optimizing the mechanisms of obtaining these revenues which will contribute to the reduction of shadowing in pay, an increase in official income, which together will increase the budget revenue.

The social impact will manifest itself in the formation of more sophisticated social norms that will positively transform the society in the direction of common principles of social justice.

Considering that the income of households in Ukraine, comparable with the volume of GDP, lags far behind and affects the achievement of the SDGs, there is a need to continue research in this area.

\section{REFERENCES}

About the All-Ukrainian Population Census: Law of Ukraine dated 19.10.2000 No. 2058-III. (2000). Retrieved October 10, 2019, from http://zakon2.rada.gov.ua/laws/show/205814.

About the Strategy of Sustainable Development "Ukraine-2020": Decree of the President of Ukraine No. 5/2015 dated January 12, 2015 (2015). Retrieved October 5, 2019, from http://zakon5.rada.gov.ua/laws/show/5/201 5

Atkinson A. B. (1970). On the Measurement of Inequality. Journal of Economic Theory, 2, 244-263.

Becker, G. S. (1957). The Economics of Discrimination. The University of Chicago Press. 178.

Berezhna, L. V., Snytyuk, O. I. (2016). Economic and mathematical models in foreign economic activity: a textbook for students of economic areas of training, Kyiv: Condor-Publisher. 386 p. (Original work was written in Ukrainian).

Berezina, O. Yu. Servatinska I. M. (2018). Contemporary challenges of household income differences in Ukraine. Scientific development and achievements: monograph. London, Sciemcee Publishing, 121-128.

Bosch, G., Kalina, T. (2016). The erosion of the German middle class: the end of the 'leveled 
out middle-class society'? In: VaughanWhitehead, D. (ed.): Europe's disappearing middle class?. Cheltenham: Elgar.

Chandra S., Yadoo J. U. S. Household Incomes Rose to a Record in 2016 as Poverty Fell. Retrieved September 20, 2019, from https://www.bloomberg.com/news/articles/ 2017-09-12/u-s-household-incomes-roseto-record-in-2016-as-poverty-fell .

Chart of the day: Which countries have the largest share of global household wealth. Retrieved September 28, 2019 from https: //www.weforum.org/agenda/2018/11/chartof-the-day-which-countries-have-thebiggest-share-of-global-household-wealth/

Dalton H. (1920). The measure of the inequality of Income. The Economic Journal, 119, 348361.

Deaton, A. (1997). The Analysis of Household Surveys: A Microeconometric Approach to Development Policy. Baltimore: The John Hopkins University Press.

Del'anno R., Schneider F. (2005). The shadow economy of Italy and other OECD countries: What do we know? Linz: The University of Linz, Department of Economics, Discussion Paper, forthcoming in Journal of Public Finance and Public Choice.

Global Partnership for Local Sustainable Development: ModernTrends and Best Practices: monograph / [ed. by L. O. Petkova, O. Yu. Berezina, Andrzej Kryński]. Czestochowa, 2018. 207p.

Honcharenko, I., Kunchenko-Kharchenko, V., Berezina, O. (2019). Information asymmetry as the impact factor on the financial security of the state. Proceedings of the 33rd International Business Information Management Association Conference "Education Excellence and Innovation Management through Vision 2020", ed.Khalid S. Soliman. IBIMA. 470-482.

Household Budget Surveys in the EU Methodology and Recommendations for Harmonization (1997). Eurostat. Luxembourg.

Libanova, E. M. (2014). Human development in Ukraine: a historical dimension of state social policy transformation. Institute of Demography and Social Research of Birds of
NAS of Ukraine. 215. (Original work was written in Ukrainian).

Mandybura, V. O. (2008). The population of Ukraine living standards and the problems of reforming the mechanisms of its regulation. Kyiv Higher School. 165. (Original work was written in Ukrainian).

McConnell K., Brue S. (2003). Economics: Principles, Problems, and Policies. K.: Hagar Demos, 785 pp.

National Report "Sustainable Development Goals: Ukraine" (2017). Ministry of Economic Development and Trade of Ukraine. Kyiv. 176 pp.

Objectives of sustainable development. Retrieved October 1, 2019, from http://www.un.org.ua/ua/tsili-rozvytkutysiacholittia/tsili-staloho-rozvytku.

Petkova L., Zagorulko I., Palamarchuk D. Model of the impact of household assets on labor price: the European experience. Journal of Eastern European and Central Asian Research. Vol 6. No 2 (2019). P.234-244. DOI: https://doi.org/10.15549/jeecar.v6i2.297.

Reward work, not wealth: To end the inequality crisis, we have to build an economy for ordinary people, not the rich and powerful. Retrieved October 12, 2019, from www.oxfam.org

Schneider, F. The size of the Shadow Economies of 145 Countries all over the World: First Results over the period 1999 to 2003. Retrieved September 21, 2019 from www.iza.or.

Shubina S. V, Miroshny'k O. Yu. (2010). Features of ensuring the reliability of credit relations of the system "Bank-subjects of entrepreneurial activities" Retrieved October 2, 2019, from https://rep.polessu.by/bitstream/123456789 /4311/1/73.pdf . (Original work was written in Russian).

State Statistics Service of Ukraine. Statistical collection "Differentiation of living standard", http://wwW.ukrstat.gov.ua. Retrieved October 3, 2019, from http://www.ukrstat.gov.ua. (Original work was written in Russian). 
State Statistics Service of Ukraine. Statistical collection "Households expenses and resources in Ukraine for 2018". Statistical collection "Households expenses and resources in Ukraine for 2010-2017". Retrieved October 7, 2019, from http://www.ukrstat.gov.ua. (Original work was written in Russian).

State Statistics Service of Ukraine. Statistical collection "Income and costs of the population in 2018"Retrieved October 4, 2019, from http://www.ukrstat.gov.ua. (Original work was written in Russian).

State Statistics Service of Ukraine. Statistical collection "Self-assessment of income level by households in Ukraine for 2017". Retrieved October 3, 2019, from http://www.ukrstat.gov.ua. (Original work was written in Russian).

Tanzi, V. (1999). Uses and abuses of estimates of the underground economy. The Economic Journal, 109/456, 338-340.

The historic new sustainable development agenda has been adopted unanimously by the $193 \mathrm{UN}$ member states. Retrieved October 3, 2019, from http://www.un.org.ua/ua/informatsiinyitsentr/news/3579-2015-09-28-12-06-08istorichniy-noviy-poryadok-den.

The world needs 2 billion to build new homes over the next 80 years Retrieved October 1 , 2019, from https://www.weforum.org/agenda/2018/03/ the-world-needs-to-build-more-than-twobillion-new-homes-over-the-next-80-years

Yuri S., Kizima T. (2008). Household Finance: Theoretical Approaches to the Treatment of Essence. Finance of Ukraine. Vol. 8. P. 3-10. (Original work was written in Ukrainian).

\section{ABOUT THE AUTHORS}

Olena Berezina, email: o.berezina@chdtu.edu.ua

Dr. Olena Berezina is the Professor of the Finance at Cherkasy State Technological University, Ukraine. She received her Specialist Degree in International Economics, $\mathrm{PhD}$ in Demography, Labor Economics, Social Economics and Policy. Her thesis for getting the degree of the PhD in Economic Sciences is devoted to Social responsibility of corporations and sociallabor relations. Her current research interest is in the area of sustainable development, social responsibility, social economics, corporate finance \& government.

Dr. Iryna Honcharenko is the Professor and Head of the Finance Department at Cherkasy State Technological University, Ukraine. She received her Specialist Degree in Finance, $\mathrm{PhD}$ in Economics \& Management. Her thesis for getting the Degree of Doctor of Science is devoted to challenges and mechanism of State Government for Socio \& Economic Development. Her current research interest is in the area of international finance, insurance, state government and taxation.

Dr. Lesia Berezhna is an Associate Professor of the Finance Department at Cherkasy State Technological University, Ukraine. She received her master's degree in information Technologies in Management, $\mathrm{PhD}$ in Economic-Mathematical Modeling. Her thesis for getting the degree of the $\mathrm{PhD}$ in Economic Sciences is devoted to modeling the logistics of continuous production. Dr. Berezhna current research interest is in the area of economic and mathematical methods and models in finance and international economy, financial inclusion, cashless economics, macroprudential and monetary policy. 